\title{
PENGARUH GAYA KEPEMIMPINAN, EFEKTIVITAS PENGAMBILAN KEPUTUSAN, DAN PEMBERIAN KOMPENSASI INSENTIF TERHADAP KINERJA KARYAWAN BAGIAN KEUANGAN PADA SWALAYAN GIANT MARGOREJO SURABAYA
}

\author{
NURCHOLIS \\ cholizcnick@gmail.com \\ Mahasiswa Fakultas Ekonomi dan Bisnis Universitas Narotama
}

\begin{abstract}
ABSTRAK
Penelitian ini bertujuan untuk mengetahui pengaruh gaya kepemimpinan, efektivitas pengambilan keputusan, dan pemberian kompensasi insentif terhadap kinerja karyawan bagian keuangan pada Swalayan Giant Margorejo Surabaya. Pengumpulan data menggunakan metode survey melalui penyebaran kuesioner. Teknik sampel menggunakan purposive sampling berjumlah 45 responden yang disebar kepada karyawan bagian keuangan di Swalayan Giant Margorejo Surabaya. Metode analisis data yang digunakan adalah analisis kuantitatif dengan menggunaakan uji validitas, uji reliabilitas, uji asumsi klasik, dan uji regresi linier berganda. Hasil penelitian ini menunjukkan bahwa gaya kepemimpinan berpengaruh signifikan terhadap kinerja karyawan. Efektifitas pengambilan keputusan tidak berpengaruh signifikan terhadap kinerja karyawan. Kompensasi insentif berpengaruh signifikan terhadap kinerja karyawan.

Kata kunci: Gaya Kepemimpinan, Pengambilan Keputusan, Kompensasi

Insentif, dan Kinerja Karyawan.
\end{abstract}

\section{PENDAHULUAN}

\subsection{Latar Belakang}

Akuntansi merupakan suatu sistem untuk menghasilkan informasi keuangan yang digunakan oleh para pemakainya dalam proses pengambilan keputusan bisnis. Pemilihan dan penetapan suatu keputusan bisnis tersebut melibatkan aspek-aspek keperilakuan, baik dari pihak pelaksana/penyusun informasi maupun dari pihak pemakai akuntansi (Ikhsan dan Ishak:2008).

Pihak pelaksana/penyusun informasi akuntansi salah satunya adalah karyawan yang bekerja dibagian keuangan, yaitu seseorang yang mengoperasikan sistem informasi akuntansi. Oleh sebab itu, karyawan dituntut untuk meningkatkan kinerjanya agar informasi yang dihasilkan dapat bermanfaat bagi kelangsungan perusahaan. Dalam upaya peningkatan kinerja, maka diperlukan standar yang dapat dijadikan ukuran atau kriteria bagi karyawan, terutama dalam pengolahan informasi akuntansi.

Karyawan bagian keuangan selaku pelaksana/penyusun informasi akuntansi diharapkan mempunyai kompetensi agar kinerjanya dapat terkontribusi terhadap pencapaian tujuan yang selanjutnya menghasilkan outcome yang bermanfaat bagi kontinuitas perusahaan. Menurut Mangkunegara (2000), faktor yang mempengaruhi kinerja adalah kemampuan (ability) dan faktor motivasi.

Gaya kepemimpinan dan efektivitas pengambilan keputusan oleh pimpinan, serta pemberian kompensasi insentif dari perusahaan diyakini dapat memotivasi karyawan dalam meningkatkan kinerjanya. Gaya kepemimpinan merupakan cermin dari sikap seorang pemimpin kepada 
bawahannya. Seorang pemimpin diharapkan dapat mengarahkan dan memotivasi perilaku individu guna meningkatkan kinerja karyawan bagian keuangan. Jika kinerja karyawan tersebut baik, maka akan menghasilkan informasi keuangan yang handal untuk perusahaan. Menurut Winardi (2000) gaya kepemimpinan tidak hanya sebatas individu harus memperhatikan gaya konsisten dalam semua aktivitasnya, melainkan harus bersifat sefleksibel mungkin dan menyesuaikan gayanya dengan situasi spesifik dari individuindividu yang bersangkutan.

Oleh karenanya gaya kepemimpinan perlu diperhatikan bagi setiap pimpinan-pimpinan perusahaan pada umumnya. Efektivitas pengambilan keputusan dalam manajemen diperlukan guna mengambil dan menentukan suatu tindakan sebagai cara pemecahan masalah. Efektivitas erat kaitannya dengan ketepatan waktu pengambilan keputusan yang berhubungan dengan informasi keuangan perusahaan.

Menurut Hasan (2002) pengambilan keputusan adalah suatu pendekatan yang sistematis terhadap hakikat alternatif yang dihadapi dan mengambil tindakan yang menurut perhitungan merupakan tindakan yang paling tepat. Tindakan yang tepat ini dinilai berpengaruh terhadap pekerjaan yang dilakukan karyawan bagian keuangan ditiap - tiap perusahaan. Pemberian kompensasi insentif berupa gaji, bonus, dan tunjangan - tunjangan lainnya seharusnya dimiliki oleh suatu perusahaan guna memberikan balas jasa kepada karyawan atas hasil kerjanya, sehingga karyawan termotivasi untuk menyelesaikan pekerjaannya dengan baik dan benar.

Menurut Luthans (2006) penghargaan organisasi memiliki sejumlah bentuk yang berbeda, meliputi uang (gaji, bonus, insentif), penghargaan, dan benefit. Oleh karena itu perusahaan di tuntut untuk dapat memberikan kompensasi kepada karyawannya.

Dalam penelitian ini yang menjadi objek adalah karyawan bagian keuangan pada Swalayan Giant Margorejo Surabaya. Swalayan merupakan sebuah toko yang menjual segala kebutuhan sehari-hari seperti bahan makanan, minuman, sembako, keperluan 3 rumah tangga, dan lain sebagainya.

Pemilihan objek ini didasarkan atas pertimbangan pesatnya perkembangan Swalayan Giant Margorejo Surabaya. Berdasarkan penjelasan diatas, maka dapat digambarkan pentingnya gaya kepemimpinan, efektivitas pengambilan keputusan, dan pemberian kompensasi insentif terhadap kinerja karyawan. Dengan alasan tersebut, maka peneliti mengambil judul "Pengaruh Gaya Kepemimpinan, Efektivitas Pengambilan Keputusan, dan Pemberian Kompensasi Insentif Terhadap Kinerja Karyawan Bagian Keuangan pada Swalayan Giant Margorejo Surabaya".

\subsection{Rumusan Masalah}

Rumusan masalah dalam penelitian ini adalah apakah gaya kepemimpinan, efektivitas pengambilan keputusan, dan kompensasi insentif berpengaruh terhadap kinerja karyawan baik secara parsial maupun simultan pada Swalayan Giant Margorejo Surabaya?.

\subsection{Tujuan Penelitian}

Tujuan penelitian adalah untuk mengetahui pengaruh gaya kepemimpinan, efektivitas pengambilan keputusan, dan kompensasi insentif terhadap kinerja karyawan baik secara parsial maupun simultan pada Swalayan Giant Margorejo Surabaya. 


\subsection{TINJAUAN PUSTAKA DAN PENGEMBANGAN HEPOTESIS}

\subsubsection{Akuntansi Keperilakuan}

Akuntansi keperilakuan adalah bagian dari disiplin ilmu akuntansi yang mengkaji hubungan antara perilaku manusia dan sistem akuntansi, serta dimensi keperilakuan dari organisasi dimana manusia dan sistem akuntansi berada dan diakui keberadaannya (Suartana:2010). Menurut Ikhsan dan Ishak (2008) akuntansi keperilakuan merupakan aspek penting dalam suatu sistem untuk menghasilkan informasi keuangan yang digunakan oleh para pemakainya dalam proses pengambilan keputusan bisnis.

Tujuan informasi tersebut adalah memberikan petunjuk dalam memilih tindakan yang paling baik untuk mengalokasikan sumber daya yang langka pada aktivitas bisnis dan ekonomi. Dengan demikian, akuntansi tidak dapat dilepaskan dari aspek perilaku manusia serta kebutuhan organisasi akan informasi yang dapat dihasilkan oleh akuntansi.

Menurut Schiff dan Lewin dalam Suartana (2010) ada lima aspek penting dalam akuntansi keperilakuan, yaitu:

\section{Teori Perusahaan dan Keperilakuan Manajerial}

Teori organisasi modern memandang adanya interaksi antar elemen organisasi untuk mendukung tujuan organisasi. Secara lebih spesifik, teori organisasi modern berkonsentrasi pada perilaku pengarahan tujuan perusahaan, motivasi, dan karakteristik penyelesaian masalah.

Tujuan organisasi dipandang sebagai hasil dari proses saling mempengaruhi dalam perusahaan, penentuan 4 batas-batas dalam pengambilan keputusan, dan peranan dari pengendalian internal yang diciptakan oleh perusahaan. Sedangkan motivasi dipandang sebagai salah satu faktor penentu kinerja individu/kelompok dalam organisasi.

\section{Penganggaran dan Perencanaan}

Fokus dari area ini adalah formulasi tujuan organisasi dan interaksi perilaku individu. Beberapa dimensi penting dalam area ini adalah proses partisipasi penganggaran, level kesulitan dalam pencapaian tujuan, level aspirasi, dan adanya konflik antara tujuan individual dengan ujuan organisasi. Keselarasan antara tujuan individu dengan tujuan organisasi menjadi kerangka manajerial mengembangkan organisasi.

\section{Pengambilan Keputusan}

Fokus dalam bidang ini adalah teori-teori dan model-model tentang pengambilan keputusan. Ada teori normatif, paradoks, dan model deskriptif dalam pengambilan keputusan. Teori normatif adalah bagaimana seharusnya orang mengambil keputusan. Paradoks adalah sesuatu yang bertentangan dengan teori normatif, sedangkan model deskriptif menjelaskan apa yang terjadi ketika orang mengambil keputusan berdasarkan data-data empiris yang ada. 


\section{Pengendalian}

Aspek pengendalian sangat penting dalam organisasi perusahaan. Semakin besar perusahaan, memerlukan tindakan pengendalian yang semakin insentif. Pengendalian selalu dihubungkan dengan pengukuran kinerja dan adaptasi individu terhadap pengendalian. Dimensi penting dalam pengendalian adalah struktur organisasi, pengendalian internal, desentralisasisentralisasi, dan hubungan antara hirarki administrasi. Perkembangan terbaru dalam pengendalian internal adalah diakuinya lingkungan pengendalian sebagai salah satu kunci (key success factor) dalam mengendalikan operasional perusahaan.

\section{Pelaporan Keuangan}

Aspek keperilakuan dalam pelaporan keuangan meliputi perilaku perataan laba dan keandalan informasi akuntansi dan relevansi informasi akuntansi bagi investor. Perataan laba adalah bagian dari manajemen laba yang disebabkan oleh pihak manajemen mempunyai informasi privat untuk kepentingan dirinya.

Manajemen laba intinya adalah masalah keperilakuan, yaitu perilaku manajemen yang mementingkan dirinya sendiri dalam suatu pola keagenan. Ruang lingkup manajemen laba termasuk didalamnya adalah pemilihan metode akuntansi, estimasi, klasifikasi, dan format yang digunakan dalam pengungkapan yang bersifat wajib.

\subsubsection{Kinerja Karyawan Bagian Keuangan}

Kinerja adalah hasil kerja secara kualitas dan kuantitas yang dicapai oleh seorang pegawai/karyawan dalam melaksanakan tugasnya sesuai dengan tanggungjawab yang diberikan kepadanya (Mangkunegara:2000).

Kinerja (performance) mengacu kepada kadar pencapaian tugastugas yang membentuk sebuah pekerjaan karyawan. Kinerja merefleksikan seberapa baik karyawan memenuhi persyaratan sebuah pekerjaan. Sering disalah tafsirkan sebagai upaya (effort) yang mencerminkan energi yang dikeluarkan, namun kinerja diukur dari segi hasil. Kinerja karyawan adalah tingkat para karyawan mencapai persyaratan kerjanya (Simamora dalam Saputra: 2010).

Karyawan bagian keuangan diperusahaan sangat diperlukan guna membantu manajemen dalam menyediakan informasi yang digunakan untuk mengambil keputusan. Menurut Ikhsan dan Ishak (2008) pemilihan dan penetapan suatu keputusan bisnis tidak dapat lepas dari aspek perilaku manusia serta kebutuhan organisasi akan informasi yang dihasilkan oleh akuntansi.

Dengan adanya pengertian-pengertian diatas, maka sudah dapat dipastikan bahwa kinerja karyawan bagian keuangan merupakan aspek penting yang harus diperhatikan dalam perusahaan, karena dengan meningkatnya kinerja akan menghasilkan outcome yang baik serta tercapainya visi dan misi perusahaan.

\subsubsection{Gaya Kepemimpinan}

Menurut Wirawan (2002) pemimpin adalah orang yang dikenal oleh individu atau kelompok dan berusaha mempengaruhi para pengikutnya untuk merealisir visinya baik secara langsung 
maupun tidak langsung. Pemimpin merupakan unsur penting dari kepemimpinan, tanpa pemimpin tidak ada kepemimpinan.

Sashkin (2011) mengatakan bahwa kepemimpinan yang bermakna menjadi penting karena akan menjadikan suatu perbedaan. Makna kepemimpinan secara eksplisit memadukan tiga aspek utama kepemimpinan, yaitu kepribadian, perilaku, dan konteks keorganisasian. Perbedaan ini muncul dalam kehidupan para pengikut di dalam suatu kelompok atau organisasi.

Menurut G.R. Terry dalam Winardi (2000) "Leadership is the relationship in which one person, or the leader, influences others to work together willingly on related tasks to attain that which the leader desires." Dari definisi tersebut dapat disimpulkan bahwa aktivitas memimpin pada hakikatnya meliputi suatu hubungan, adanya satu orang yang mempengaruhi orang-orang lain agar mereka mau bekerja ke arah pencapaian sasaran tertentu.

Hubungan antara pemimpin dan mereka yang dipimpin bukanlah hubungan satu arah, tetapi juga harus ada interaksi antara keduanya. Oleh sebab itu hendaknya pemimpin memiliki gaya dalam dirinya agar yang dipimpin dapat mengikuti arahan dari pemimpin itu sendiri. Gaya dalam kepemimpinan merupakan sikap atau perilaku pemimpin dalam suatu organisasi atau perusahaan yang dipimpinnya.

Mengenai gaya kepemimpinan, Luthans (2006) menyatakan sebagai berikut: "The word "style" is roughtly equivalent to the way the leader influences follower. The accompanying, International Application Example indicates that this style may be influenced by culture..." Menurut pengarang ini gaya kepemimpinan adalah cara pemimpin mempengaruhi para pengikutnya. Ia menyatakan bahwa gaya kepemimpinan dipengaruhi oleh budaya.

Lebih lanjut Wirawan (2002) mendefinisikan gaya kepemimpinan sebagai pola perilaku pemimpim dalam mempengaruhi para pengikutnya. Pengertian pola perilaku bukan dalam pengertian statis akan tetapi dalam pengertian dinamis. Gaya kepemimpinan seorang pemimpin dapat berubah-ubah tergantung pengikut dan situasinya. Dengan kata lain seorang pemimpin dapat mempergunakan sejumlah pola perilaku yang berbeda dalam mempengaruhi para pengikutnya.

Berdasarkan uraian diatas, maka dapat diambil kesimpulan bahwa gaya kepemimpinan adalah perilaku dan strategi yang digunakan pimpinan dalam menjalankan tugasnya untuk mempengaruhi kinerja bawahan guna mencapai tujuan suatu organisasi atau perusahaan.

\subsubsection{Pengambilan keputusan}

Pengertian pengambilan keputusan menurut beberapa ahli adalah sebagai berikut:

1. George R. Terry, pengambilan keputusan adalah pemilihan alternatif perilaku (kelakuan) tertentu dari dua atau lebih alternatif yang ada.

2. S.P. Siagian, pengambilan keputusan adalah suatu pendekatan yang sistematis terhadap hakikat alternatif yang dihadapi dan mengambil tindakan yang menurut perhitungan merupakan tindakan yang paling tepat. 
3. James A.F. Stoner, pengambilan keputusan adalah proses yang digunakan untuk memilih suatu tindakan sebagai cara pemecahan masalah. (Hasan:2002) Dari pengertian-pengertian pengambilan keputusan diatas, dapat disimpulkan bahwa pengambilan keputusan merupakan suatu proses pemilihan alternative terbaik dari beberapa alternatif secara sistematis untuk ditindaklanjuti sebagai suatu cara pemecahan masalah. Sedangkan teori pengambilan keputusan adalah teori-teori atau teknik-teknik atau pendekatan-pendekatan yang digunakan dalam suatu proses pengambilan keputusan.

\subsubsection{Kompensasi Insentif}

Menurut Hasibuan (2007) kompensasi adalah semua pendapatan yang berbentuk uang, barang langsung atau tidak langsung yang diterima karyawan sebagai imbalan atas jasa yang diberikan kepada perusahaan. Menurut Rachmawati (2008) kompensasi adalah keseluruhan balas jasa yang diterima oleh karyawan sebagai balas jasa dari pelaksanaan pekerjaan di organisasi dalam bentuk uang atau lainnya yang dapat berupa gaji, upah, bonus, insentif, dan tunjangan. Menurut Gomes (2003) kompensasi adalah segala sesuatu yang diterima oleh pekerja sebagai balas jasa atas kerja mereka.

Masalah kompensasi berkaitan dengan konsistensi internal dan konsistensi eksternal. Konsistensi internal berkaitan dengan konsep penggajian relatif dalam organisasi. Sedangkan konsistensi eksternal berkaitan dengan tingkat relatif struktur penggajian diluar organisasi. Berdasarkan pengertian-pengertian diatas, maka dapat disimpulkan bahwa kompensasi adalah imbalan atau pengharagaan yang diberikan perusahaan kepada karyawan sebagai balas jasa atas pekerjaan yang dilakukan melebihi standar yang telah ditentukan.

\subsubsection{Pengembangan Hipotesis}

Menurut Sehfudin (2011) dalam penelitiannya menyatakan bahwa gaya kepemimpinan mempunyai pengaruh yang signifikan terhadap kinerja karyawan. Berdasarkan penelitian tersebut dapat ditarik kesimpulan awal, yaitu:

\section{Hipotesis 1 :}

Diperdugakan ada pengaruh gaya kepemimpinan terhadap kinerja karyawan bagian keuangan. Menurut Kasanaton (2012) dalam penelitiannya menyatakan bahwa efektivitas pengambilan keputusan mempunyai pengaruh yang signifikan terhadap kinerja karyawan bagian keuangan. Berdasarkan penelitian tersebut dapat ditarik kesimpulan awal, yaitu:

\section{Hipotesis 2 :}

Diperdugakan ada pengaruh efektivitas pengambilan keputusan terhadap kinerja karyawan bagian keuangan. Menurut Vabiola (2012) dalam penelitiannya menyatakan bahwa kompensasi mempunyai pengaruh yang signifikan terhadap kinerja karyawan bagian keuangan. Berdasarkan penelitian tersebut dapat ditarik kesimpulan awal, yaitu:

\section{Hipotesis 3 :}

Diperdugakan ada pengaruh pemberian kompensasi insentif terhadap kinerja karyawan bagian keuangan. Berdasarkan ketiga hipotesis diatas dapat ditarik kesimpulan awal dari ketiga variabel bebas, yaitu: 
Hipotesis 4 :

Diperdugakan ada pengaruh gaya kepemimpinan, efektivitas pengambilan keputusan, dan pemberian kompensasi 8 insentif secara simultan terhadap kinerja karyawan bagian keuangan.

\subsection{METODE PENELITIAN}

Penelitian ini menggunakan dua variabel, yaitu variabel independen dan variabel dependen. Variabel bebas (independent variable) merupakan variabel stimulus atau variabel yang mempengaruhi variabel lain. Variabel bebas pengaruhnya diukur dan dipilih oleh peneliti untuk menentukan hubungannya dengan suatu gejala yang diobservasi dalam kaitannya dengan variabel lain (Sarwono: 2010). Variabel bebas dalam penelitian ini adalah gaya kepemimpinan (X1), efektivitas pengambilan keputusan (X2), dan kompensasi insentif (X3). Variabel terikat (dependent variable) adalah variabel yang memberikan reaksi/respon jika dihubungkan dengan variabel bebas (Sarwono:2010). Variabel ini keberadaannya diamati dan diukur untuk menentukan pengaruh yang disebabkan oleh variabel bebas. Adapun yang menjadi variabel terikat dalam penelitian ini adalah kinerja karyawan (Y).

Populasi dalam penelitian ini adalah karyawan bagian keuangan pada Swalayan Giant Margorejo Surabaya. Sedangkan sampel adalah sebagian dari populasi. Dengan mempelajari sampel, peneliti akan mampu menarik kesimpulan yang dapat degeneralisasikan terhadap populasi penelitian. Teknik pengambilan sampel yang digunakan adalah dengan menggunakan purposive sampling, yaitu pengambilan sampel berdasarkan pertimbangan tertentu. Pertimbangan tersebut didasarkan pada kepentingan atau tujuan penelitian yang dapat memberikan informasi yang diinginkan (Suharyadi:2009).

Jenis data yang digunakan adalah data kuantitatif, yaitu penelitian yang menggunakan pengujian-pengujian hipotesis dengan alat uji statistik melalui software SPSS 17. Sumber data yang digunakan adalah data primer dan data sekunder. Data primer dalam penelitian ini yaitu observasi dan data yang diperoleh melaui kuesioner. Sedangkan data sekunder diperoleh dari perpustakaan dan sumber-sumber lain seperti internet dan media sosial.

Metode pengumpulan data yang digunakan dalam penelitian ini adalah wawancara secara tidak langsung, yaitu melalui penyebaran kuesioner secara personal. Pengujian melalui kuesioner digunakan untuk mengetahui seberapa besar pengaruh gaya kepemimpinan, efektivitas pengambilan keputusan, dan pemberian kompensasi insentif terhadap kinerja karyawan. Skala yang digunakan dalam kuesioner ini adalah skala likert. Indikator yang digunakan pada setiap pertanyaan kuesioner bersumber dari penelitian terdahulu yang membahas variabel yang sama.

Metode analisis data menggunakan uji kualitas data, uji asumsi klasik, dan uji regresi linier berganda. Uji kualitas data terdiri dari validitas dan reliabilitas. Uji asumsi klasik terdiri dari normalitas, multikolinieritas, dan 9 heterokedastisitas. Sedangkan uji regresi linier berganda 
digunakan untuk menguji hipotesis penelitian, yaitu menggunakan uji signifikansi parsial (uji t) dan uji signifikansi simultan (uji F), serta uji koefisien determinasi.

\subsection{PEMBAHASAN}

\subsubsection{Deskripsi Objek Penelitian}

Objek penelitian ini adalah karyawan bagian keuangan pada Swalayan Giant Margorejo Surabaya. Swalayan merupakan sebuah toko yang menjual segala kebutuhan sehari-hari seperti bahan makanan, minuman, sembako, barang elektronik, keperluan rumah tangga, dan lain sebagainya.

Dalam menentukan populasi, peneliti menetapkan beberapa kriteria tertentu untuk membatasi masalah penelitian. Adapun yang menjadi kriteria dalam mengambil populasi yaitu swalayan atau supermarket (tidak termasuk minimarket) yang sudah berdiri minimal 3 tahun dan terdaftar di Dinas Perindustrian dan Perdagangan Kota Surabaya.

Berdasarkan data yang diperoleh dari Dinas Perindustrian dan Perdagangan, terdapat 25 swalayan yang terdaftar di Surabaya. Dari 25 swalayan yang ada kemudian diseleksi menurut kriteria penelitian, dan terdapat 11 swalayan yang memenuhi kriteria. Dari 11 swalayan tersebut yang bersedia menjadi objek penelitian hanya 6 swalayan.

Penyebaran kuesioner kepada responden disemua swalayan berjumlah 60 kuesioner, dan hanya kembali 52. Selanjutnya dari 52 kuesioner yang kembali terdapat jawaban data responden yang tidak lengkap, dan diperoleh 45 kuesioner yang dapat diolah. Berdasarkan kuesioner tersebut, maka dapat ditentukan banyaknya sampel dalam penelitian ini adalah berjumlah 45 responden.

\subsubsection{Uji Kualitas Data}

\section{Uji Validitas}

Pengujian validitas data dalam penelitian ini menggunakan metode korelasi Bivariate Pearson (Korelasi Pearson Product Moment). Priyatno (2010) mengemukakan bahwa Analisis ini dilakukan dengan cara mengkorelasikan masing-masing skor item dengan skor total. Skor total adalah penjumlahan dari keseluruhan item. Item-item pertanyaan yang berkorelasi signifikan dengan skor total menunjukkan item-item tersebut mampu memberikan dukungan dalam mengungkap apa yang ingin diungkap.

Pengujian menggunakan uji dua sisi dengan taraf signifikansi 0,05 . Kriteria pengujian kriteria pengujiannya adalah jika $r$ hitung $\geq r$ tabel maka instrumen atau item-item pernyataan berkorelasi signifikan terhadap skor total (dinyatakan valid). Jika nilai $r$ hitung $\leq \mathrm{r}$ tabel, maka item pernyataan dinyatakan 10 tidak valid. Rumus yang digunakan untuk mencari nilai $\mathrm{r}$ tabel adalah $\mathrm{df}=\mathrm{n}-2$. Jumlah data $(\mathrm{n})=45$, maka didapat $\mathrm{r}$ tabel sebesar 0,294. Berdasarkan pada lampiran I, maka semua item pertanyaan dari setiap variabel memiliki $r$ hitung diatas 0,294 . Artinya dapat disimpulkan item pertanyaan pada penelitian ini dinyatakan valid (dapat digunakan) untuk menguji setiap variabel independen dan variabel dependen. 
Variabel Gaya Kepemimpinan

\begin{tabular}{|l|l|l|l|}
\hline Item / Pernyataan & r hitung & r tabel & Keterangan \\
\hline GK 1 & 0,684 & 0,294 & Valid \\
GK 2 & 0,570 & 0,294 & Valid \\
GK 3 & 0,621 & 0,294 & Valid \\
GK 4 & 0,669 & 0,294 & Valid \\
GK 5 & 0,636 & 0,294 & Valid \\
\hline
\end{tabular}

Sumber: Data primer yang diolah

Variabel Efektivitas Pengambilan Keputusan

\begin{tabular}{|l|l|l|l|}
\hline Item / Pernyataan & r hitung & r tabel & Keterangan \\
\hline PK 1 & 0,731 & 0,294 & Valid \\
PK 2 & 0,786 & 0,294 & Valid \\
PK 3 & 0,741 & 0,294 & Valid \\
PK 4 & 0,662 & 0,294 & Valid \\
PK 5 & 0,841 & 0,294 & Valid \\
\hline
\end{tabular}

Sumber: Data primer yang diolah

Variabel Kompensasi Insentif

\begin{tabular}{|l|l|l|l|}
\hline Item / Pernyataan & r hitung & r tabel & Keterangan \\
\hline KI 1 & 0,478 & 0,294 & Valid \\
KI 2 & 0,501 & 0,294 & Valid \\
KI 3 & 0,672 & 0,294 & Valid \\
KI 4 & 0,771 & 0,294 & Valid \\
KI 5 & 0,711 & 0,294 & Valid \\
\hline
\end{tabular}

Sumber: Data primer yang diolah

Variabel Kinerja Karyawan

\begin{tabular}{|l|l|l|l|}
\hline Item / Pernyataan & r hitung & r tabel & Keterangan \\
\hline KK 1 & 0,643 & 0,294 & Valid \\
KK 2 & 0,664 & 0,294 & Valid \\
KK 3 & 0,714 & 0,294 & Valid \\
KK 4 & 0,584 & 0,294 & Valid \\
KK 5 & 0,632 & 0,294 & Valid \\
\hline
\end{tabular}

Sumber: Data primer yang diolah

2. Uji Reliabilitas 
Pengukuran reliabilitas dalam penelitian ini adalah dengan menggunakan koefisien alpha. Koefisien alpha bisa diukur dengan menggunakan uji statistic cronbach alpha. Suatu construct dikatakan reliabel jika memberikan nilai cronbach alpha > 0,60 (Sekaran:2006). Berdasarkan lampiran II, hasil uji reliabilitas untuk variabel gaya kepemimpinan adalah sebesar 0,633, efektivitas pengambilan keputusan sebesar 0,810, dan kompensasi insentif sebesar 0,615, serta variabel kinerja karyawan sebesar 0,659. Semua variabel tersebut dinyatakan reliabel, karena lebih besar dari 0,60.

Uji Reliabilitas

\begin{tabular}{|l|l|l|}
\hline Variabel & $\begin{array}{l}\text { Cronbach } \\
\text { Alpha }\end{array}$ & Keterangan \\
\hline Gaya Kepemimpinan & 0,633 & Reliabel \\
Pengambilan Keputusan & 0,810 & Reliabel \\
Kompensasi Insentif & 0,615 & Reliabel \\
Kinerja Karyawan & 0,659 & Reliabel \\
\hline
\end{tabular}

Sumber: Data primer yang diolah

\subsubsection{Uji Asumsi Klasik}

\section{Uji Normalitas}

Uji normalitas digunakan untuk melihat apakah dalam model regresi variabel terikat dan variabel bebas keduanya mempunyai distribusi normal ataukah tidak. Model regresi yang baik adalah model regresi yang berdistribusi normal (Wijaya, 2012). Cara pertama yang dapat dilakukan dalam pengujian normalitas adalah dengan analisis grafik, yaitu dengan melihat grafik histogram dan grakfik normal plot. Suatu histogram dikatakan normal jika pola distribusi berada ditengah-tengah serta menunjukkan kenaikan dan penurunan yang stabil. Berdasarkan lampiran III, histogram menunjukkan grafik naik dengan stabil, walaupun penurunannya tidak terlalu sifnifikan. Dengan ini maka dapat dikatakan bahwa pola distribusi mendekati normal. Sedangkan pada Analisis menggunakan grafik normal plot, dapat dijelakan bahwa data cenderung lurus mengikuti garis diagonal dan tidak ada yang terletak jauh dari garis sehingga dapat disimpulkan data dalam penelitian ini terdistribusi secara normal. Cara kedua untuk menentukan normalitas data adalah pengujian statistik menggunakan uji Kolmogorov Smirnov. Suatu data dikatakan normal jika nilai sig > 0,05 (Ghozali:2007). Berdasarkan hasil pengujian kolmogorov diperoleh nilai signifikan 0,614 lebih besar dari 0,05, artinya dapat disimpulkan bahwa data residual dalam penelitian ini terdistribusi normal. Hasil ini konsisten dengan dengan uji sebelumnya, yaitu analisis grafik histogram dan grafik normal plot.

\section{Uji Multikolonieritas}

Uji multikolinieritas bertujuan untuk mengui apakah model regresi ditemukan adanya korelasi antar variabel bebas (independen). Model regresi yang baik seharusnya tidak terjadi korelasi di antara variabel independen. Menurut Ghozali (2007) pengujian multikolinieritas dapat dilihat dari nilai tolerance dan variance Inflation factor (VIF). Nilai pembanding yang umum dipakai untuk menunjukkan adanya multikolinieritas adalah nilai Tolerence $<0,10$ atau sama dengan nilali VIF > 10. Berdasarkan tabel pada lampiran IV, nilai tolerance dari 
ketiga variabel independen lebih besar dari 0,10. Hasil perhitungan nilai VIF juga menunjukkan hal yang sama, tidak ada satu variabel independen yang memiliki nilai VIF lebih dari 10. Jadi dapat disimpulkan bahwa tidak terjadi multikolinieritas antar variabel independen dalam model regresi ini.

\section{Uji Heterokedastisitas}

Uji heterokedastisitas bertujuan untuk menguji apakah dalam model regresi terjadi ketidaksamaan varian dari residual satu pengamatan ke pengamatan yang lain. Model regresi yang baik adalah yang homokedastisitas atau tidak terjadi heterokedastisitas (Ghozali, 2007).

Cara pertama untuk melihat adanya problem heterokedastisitas adalah dengan melihat grafik plot antara nilai prediksi variable terikat (ZPRED) dengan residualnya (SRESID). Berdasarkan grafik pada lampiran V, dapat dilihat titik-titik menyebar secara acak, baik di atas maupun di bawah angka 0 dari sumbbu $Y$ dan tidak membentuk suatu pola tertentu. Jadi dapat disimpulkan tidak terjadi heterokedastisitas dalam model regresi ini.

Cara kedua yang lebih akurat dalam pengujian multikolinieritas adalah dengan uji glejser, yaitu digunakan untuk meregresi nilai absolut residual terhadap variabel independen. Jika nila signifikan variabel independen $<0,05$, maka ada indikasi terjadi heterokedastisitas (Ghozali:2007). Berdasarkan tabel pada lampiran V, diperoleh nilai signifikan ketiga variabel independen > 0,05, artinya dapat disimpulkan bahwa model regresi dalam penelitian ini konsisten dengan pengujian menggunakan grafik scatterplot, yaitu tidak terjadi heterokedastisitas.

\subsubsection{Uji Regresi Linier Berganda}

\section{Uji Signifikansi Parsial (uji t)}

Uji signifikansi parsial digunakan untuk menunjukkan seberapa jauh pengaruh satu variabel independen secara individu dalam menerangkan variabel dependen. Pengambilan keputusan dalam uji $\mathrm{t}$ dapat dilihat dari tingkat signifikansi dan perbandingan $\mathrm{t}$ hitung dengan $\mathrm{t}$ tabel. Jika nilai $t$ hitung $>\mathrm{t}$ tabel dengan tingkat signifikan $<0,05$, maka hipotesis $\mathrm{H} 1$ diterima. 12 Berdasarkan tabel regresi linier berganda pada lampiran VI, dapat disimpulkan hasil analisis dari ketiga hipotesis variabel independen adalah sebagai berikut:

\section{a. Hipotesis 1}

Nilai t hitung sebesar 2,073 dengan taraf signifikan sebesar 0,044. Berdasarkan rumus n-k, didapat $t$ tabel sebesar 2,020. Dengan demikian $t$ hitung $>t$ tabel, dan nilai signifikan $<0,05$. Artinya dapat disimpulkan bahwa gaya kepemimpinan berpengaruh terhadap kinerja karyawan. Hasil ini sesuai dengan penelitian Sehfudin (2011) dan Kasanaton (2012) yang menyatakan bahwa gaya kepemimpinan mempunyai pengaruh yang signifikan terhadap kinerja karyawan.

\section{b. Hipotesis 2}

Nilai t hitung sebesar 0,599 dengan taraf signifikan sebesar 0,553. Berdasarkan rumus n-k, didapat $t$ tabel sebesar 2,020. Dengan demikian $t$ hitung $<t$ tabel, dan nilai signifikan $>0,05$. Artinya dapat disimpulkan bahwa efektivitas pengambilan keputusan tidak berpengaruh 
terhadap kinerja karyawan. Hasil ini tidak sejalan dengan penelitian yang dilakukan oleh Kasanaton (2012) yang menyatakan bahwa efektivitas pengambilan keputusan mempunyai pengaruh yang signifikan terhadap kinerja karyawan.

\section{c. Hipotesis 3}

Nilai t hitung sebesar 2,144 dengan taraf signifikan sebesar 0,038. Berdasarkan rumus n-k, didapat $t$ tabel sebesar 2,020. Dengan demikian $t$ hitung $>t$ tabel, dan nilai signifikan $<0,05$. Artinya dapat di simpulkan bahwa kompensasi insentif berpengaruh terhadap kinerja karyawan. Hasil ini sesuai dengan penelitian Saputra (2010) dan Vabiola (2012) yang menyatakan bahwa kompensasi mempunyai pengaruh yang signifikan terhadap kinerja karyawan.

\section{Uji Signifikansi Simultan (uji F)}

Uji signifikansi simultan digunakan untuk menunjukkan apakah semua variabel independen yang dimasukkan dalam model mempunyai pengaruh secara bersama-sama terhadap variabel dependen. Pengambilan keputusan dalam uji $\mathrm{F}$ dapat dilihat dari tingkat signifikansi dan perbandingan $\mathrm{F}$ hitung dengan $\mathrm{F}$ tabel. Jika nilai $\mathrm{F}$ hitung $>\mathrm{F}$ tabel dengan tingkat signifikan $<0,05$, maka hipotesis H1 diterima. Berdasarkan lampiran VI pada uji signifikansi simultan, dapat disimpulkan hasil analisis dari hipotesis keempat adalah sebagai berikut:

\section{Hipotesis 4}

Nilai $\mathrm{F}$ hitung sebesar 5,214 dengan taraf signifikan sebesar 0,004. Berdasarkan rumus n-k dan $\mathrm{k}-1$, didapat $\mathrm{F}$ tabel sebesar 2,83. Dengan demikian $\mathrm{F}$ hitung $>\mathrm{F}$ tabel, dan nilai signifikan < 0,05. Artinya dapat disimpulkan bahwa gaya kepemimpinan, efektivitas pengambilan keputusan, dan kompensasi insentif secara bersama-sama berpengaruh terhadap kinerja karyawan.

\section{Uji Koefisien}

Determinasi Menurut Ghozali (2007), koefisien determinasi (R2) mengukur seberapa jauh kemampuan model dalam menerangkan variasi variabel dependen. Nilai R2 yang kecil berarti kemampuan variabelvariabel independen dalam menjelaskan variasi variabel dependen amat terbatas.

Berdasarkan tabel koefisien determinasi pada lampiran VI, dapat dilihat besarnya adjusted R2 adalah 0,223. Hal ini berarti 22,3\% variasi variabel dependen (kinerja karyawan) dapat dijelaskan oleh variasi dari ketiga variabel independen (gaya kepemimpinan, efektivitas pengambilan keputusan, dan kompensasi insentif). Sedangkan sisanya, 77,7\% dijelaskan oleh faktor-faktor lain diluar model penelitian. 


\subsection{PENUTUP}

\subsubsection{Kesimpulan}

Berdasarkan hasil analisis data dan pembahasan yang telah dilakukan untuk melihat pengaruh dari masing-masing variabel, maka dapat ditarik kesimpulan sebagai berikut:

1. Gaya kepemimpinan berpengaruh positif dan signifikan terhadap kinerja karyawan. Hal ini dapat dilihat dari nilai $\mathrm{t}$ hitung $>\mathrm{t}$ tabel $(2,073>2,020)$ dan nilai signifikansi < taraf signifikansi $(0,044<0,05)$.

2. Pengambilan keputusan tidak berpengaruh terhadap kinerja karyawan. Hal ini dapat dilihat dari nilai t hitung $<\mathrm{t}$ tabel $(0,599<2,020)$ dan nilai signifikansi $>$ taraf signifikansi $(0,553>$ $0,05)$.

3. Kompensasi insentif berpengaruh positif dan signifikan terhadap kinerja karyawan. Hal ini dapat dilihat dari nilai t hitung > t tabel $(2,144>2,020)$ dan nilai signifikansi < taraf signifikansi $(0,038<0,05)$.

4. Gaya kepemimpinan, pengambilan keputusan, dan kompensasi insentif secara bersamasama berpengaruh positif dan signifikan terhadap kinerja karyawan. Hal ini dapat dilihat dari nilai $\mathrm{F}$ hitung $>\mathrm{F}$ tabel $(5,214>2,83)$ dan nilai signifikansi $<$ taraf signifikan $(0,004<0,05)$

\subsubsection{Keterbatasan Penelitian}

Keterbatasan-keterbatasan dalam penelitian ini adalah sebagai berikut:

1. Penelitian ini hanya meneliti pada variabel gaya kepemimpinan, efektivitas pengambilan keputusan, pemberian kompensasi insentif, dan kinerja karyawan.

2. Pada penelitian ini responden hanya terbatas pada karyawan bagian keuangan di Swalayan Giant Margorejo Surabaya.

3. Penelitian ini hanya mengggunakan metode survey melalui kuesioner, sehingga peneliti tidak terlibat langsung dalam aktivitas perusahaan.

\subsubsection{Saran}

Berdasarkan kesimpulan dan keterbatasan dalam penelitian, maka peneliti memberikan beberapa saran yang dapat bermanfaat bagi pihak yang terkait, yaitu:

1. Pimpinan Swalayan Giant Margorejo Surabaya sebaiknya lebih memperhatikan gaya kepemimpinan (leadership) terhadap karyawannya, serta mempertahankan pemberian kompensasi insentif kepada tiap-tiap karyawan. Hal ini dikarenakan gaya kepemimpinan dan kompensasi insentif dapat meningkatkan kinerja karyawan.

2. Penelitian selanjutnya hendaknya menambahkan variabel lain yang dapat mempengaruhi kinerja karyawan, dan menguji kembali variabel efektivitas pengambilan keputusan. 
3. Sampel dalam penelitian hendaknya diperluas tidak hanya sebatas karyawan bagian keuangan, tetapi lebih kepada semua karyawan yang terlibat dalam perusahaan.

4. Penggunaan instrumen tidak hanya berupa kuesioner, juga bisa dilakukan wawancara secara langsung dengan narasumbernya agar hasil yang didapat lebih akurat, tidak terjadi persepsi yang berbeda antara responden dengan peneliti, serta menghindari tidak kembalinya kuesioner.

\section{DAFTAR PUSTAKA}

Alimudin, A. (2015). Strategi pengembangan minat wirausaha melalui proses pembelajaran. E-Jurnal Manajemen Kinerja, 1(1).

Alimudin, A., \& Sukoco, A. (2017). The Leadership Style Model That Builds Work Behavior Through Organizational Culture.

Alimudin, A., \& Sasono, A. D. (2015). Peningkatan daya saing produk konveksi usaha kecil berbasis iptek di desa tri tunggal kecamatan babat lamongan. In Seminar Nasional Teknologi Terapan SV UGM.

Alimudin, A., \& Yoga, H. (2015). Strategi meningkatkan loyalitas pada usaha kecil dan makanan disurabaya . Sustainable Competitive Advantage (SCA), 5(1).

Ghozali, Imam. 2007. Analisis Multivariate Dengan Program SPSS. Badan Penerbit UNDIP. Semarang

Gomes, Faustino Cardoso. 2003. Manajemen Sumber Daya Manusia. ANDI. Yogyakarta

Hasan, Iqbal. 2002. Teori Pengambilan Keputusan. Ghalia Indonesia. Jakarta 2010. Analisis Data Penelitian Dengan Statistik. Bumi Aksara. Jakarta

Hasibuan, Malayu. 2007. Manajemen Sumber Daya Manusia. Bumi Aksara. Jakarta

Ikhsan, Arfan dan Ishak. 2008. Akuntansi Keperilakuan. Salemba Empat. Jakarta

Irmim, Soejitno. 2005. Mengelola Potensi dan Motivasi Bawahan. Seyma Media. Jakarta

Kasanaton. 2012. Pengaruh Gaya Kepemimpinan dan Efektivitas Pengambilan Keputusan terhadap Kinerja Karyawan Bagian Keuangan. Fakultas Ekonomi Universitas Maritim Raja Ali Haji. Tanjung pinang

Luthasns, Fred. 2006. Perilaku Organisasi, edisi sepuluh. ANDI. Yogyakarta

Mangkunegara, Anwar Prabu. 2000. Manajemen Sumber Daya Manusia Perusahaan. PT Remaja Rosdakarya. Bandung 
Priyatno, Dwi. 2010. Paham Analisis Statistika Data dengan SPSS, cetakan pertama. Mediakom. Yogyakarta

Rachmawati, Ike Kusdyah. 2008. Manajemen Sumber Daya Manusia. ANDI. Yogyakarta

Rivai, Veithzal. 2004. Kepemimpinan dan Perilaku Organisasi, edisi kedua. PT Raja Grafindo. Jakarta

Sangadji, Etta Mamang dan Sopiah. 2010. Metodologi Penelitian. ANDI. Yogyakarta

Saputra, Sigit Adri. 2010. Pengaruh Kompensasi, Kepuasan Kerja, dan Motivasi Kerja Terhadap Kinerja Karyawan Bagian Akuntansi. Fakultas Ekonomi Sekolah Tinggi Ilmu Ekonomi Perbanas. Surabaya

Sarwono, Jonathan dan Ely Suhayati. 2010. Riset Akuntansi Menggunakan SPSS. Graha Ilmu. Yogyakarata

Sashkin, Marshall dan Molly. 2011. Prinsip-prinsip Kepemimpinan. Erlangga. Jakarta

Sehfudin, Arif. 2011. Pengaruh Gaya Kepemimpinan, Komunikasi Organisasi, dan Motivasi Kerja terhadap Kinerja Karyawan. Fakultas Ekonomi Universitas Diponegoro. Semarang

Sekaran, Uma. 2006. Research Methods For Business. Salemba Empat. Jakarta

Suartana, Wayan. 2010. Akuntansi Keperilakuan. ANDI. Yogyakarta

Suharyadi dan Purwanto. 2009. Statistika Untuk Ekonomi dan Keuangan Modern, edisi dua. Salemba Empat. Jakarta

Wijaya, Tony. 2012. Cepat Menguasai SPSS 20 untuk olah dan Interpretasi Data. Cahaya Atma Pustaka. Yogyakarta

Winardi. 2000. Kepemimpinan Dalam Manajemen. Rineka Cipta. Jakarta 16 Wirawan. 2002. Teori Kepemimpinan, jilid 1. Uhamka Press. Jakarta . 2003. Teori Kepemimpinan, jilid 2. Uhamka Press. Jakarta 